\title{
From mommet to ugly: An analysis of the linguistic duality and idiolect of Tess Durbeyfield in the Spanish translations of Tess of the d'Urbervilles
}

\section{De mommet a ugly. Análisis de la dualidad lingüística e idiolecto de Tess Durbeyfield en las traducciones al castellano de Tess of the d'Urbervilles}

Fecha de recepción: 27/04/2021

JULIA LÓPEZ-NARVÁEZ jlnarvaez@ucm.es

Universidad Complutense de Madrid

Fecha de aceptación: 16/09/2021

\begin{abstract}
The current study aims at critically exploring the resulting identity of Tess of the d'Urbervilles' main character, Tess Durbeyfield, in the Spanish translations through the analysis of her linguistic variation. Throughout the novel, Tess is characterised by a unique duality in linguistic variation, which shapes her identity. She is capable of using both dialectal and non-dialectal marks, which differentiates her from the rest of the novel's characters. To reach thus the goal of this research, that is, to verify whether Tess Durbeyfield's multifaceted identity is maintained in the Spanish translations, it is essential to analyse the linguistic variation of the novel's heroine in the target texts. For the project, the three Spanish translations that exist of the novel have been analysed (carried out in 1924, 1994 and 2017).

In order to reach this aforementioned objective, the strategies carried out by the different translators regarding linguistic variation will be analysed, focusing on the possible identity distortion that these decisions may entail in the heroine's characterisation. In order to observe Tess Durbeyfield's idiolect and linguistic variation, all dialogues from the novel and its corresponding translations have been analysed and classified. In the project, through selected dialogues, it will be observed whether the translation strategies regarding the heroine's linguistic variation imply a reconfiguration of Tess's identity in the target texts.
\end{abstract}

Keywords: Linguistic variation, Idiolect, Literary identity, Tess of the d'Urbervilles, Translation.

Resumen: El presente estudio tiene como objetivo explorar críticamente la identidad resultante de la protagonista de Tess of the d'Urbervilles, Tess 
Durbeyfield, a través del análisis de las traducciones castellanas de su variación lingüística. A lo largo de la novela, Tess es caracterizada por una dualidad lingüística única, la cual moldea su identidad. Es capaz de emplear tanto marcas dialectales como no dialectales, lo que la diferencia del resto de personajes de la novela. Por tanto, para alcanzar el objetivo de dicho estudio, es decir, verificar si la identidad poliédrica de Tess Durbeyfield se conserva en las traducciones castellanas, es esencial analizar la variación lingüística de la heroína en los textos meta. Para ello, en el presente trabajo se han empleado las tres traducciones que existen de la novela al castellano (realizadas en 1924, 1994 y 2017).

Para conseguir el objetivo del proyecto, se analizarán las estrategias empleadas por los diferentes traductores con respecto a la variación lingüística, prestando gran atención a la posible deformación identitaria que dichas decisiones pueden producir en la caracterización de la protagonista. Para observar el idiolecto y la variación lingüística de Tess Durbeyfield, se han analizado y clasificado todos los diálogos de la novela y sus correspondientes traducciones. En el presente proyecto, a través de los diálogos seleccionados, se podrá observar si las estrategias traductológicas con respecto a la variación lingüística de Tess implican una reconfiguración de la identidad de la protagonista en el texto meta.

Palabras clave: Variación lingüística, Idiolecto, Identidad literaria, Tess of the d'Urbervilles, Traducción.

\section{INTRODUCTION}

The translation of linguistic variation is perhaps one of the biggest challenges a translator may face. Often novels are read, where a character is identified by their dialectal speech, by a specific sociolect or by the repetitive use of a syntactical structure. Nevertheless, when contrasting original texts with their translations, there seems to be a tendency of omitting these identity traits in the target texts. In many translations, when a character has a very strong idiolect, there is a tendency towards neutralising their linguistic variation and thus, risking the distortion of the character's construction and identity.

Linguistic variation plays a crucial role in literature, as it has the power of distinguishing a character and making them unique. It is a resource quite commonly used in original texts, since it provides the narrative with very well differentiated characters. Given the importance of linguistic variation in character construction, it should be as essential in translated texts, since if omitted, this particular and inalienable characterisation will be altered. Unfortunately, the translational tradition says otherwise. In literary 
translation, there seems to be a tendency towards neutralisation, causing a possible transformation in the story and the character's identity.

The current study aims at analysing the three Spanish translations of Tess of the d'Urbervilles (Thomas Hardy, 1891), observing how the linguistic variation has been translated and verifying if the identity of the main heroine, through her idiolect, is maintained in the target text

\section{THEORETICAL BACKGROUND: LINGUISTIC VARIATION AND IDIOLECT}

Tello Fons (2012, p. 133) defines linguistic variation as the functional varieties of language that have to do with both the speaker and the context in which this variety is used. Linguistic variation is commonly classified into use-related variation (register) and user-related (dialect) (Alsina, 2020, p. 147). Even though there are different classifications regarding linguistic variation, one of the most recurring one is the classification proposed by Halliday, Mclntosh and Strevens in 1964 and accepted by experts such as Hatim and Mason (1995), Hurtado Albir (2001), Tello Fons (2011), Rica Peromingo and Braga Riera (2015). This classification divides linguistic variation into geographic dialect, temporal dialect, social dialect, standard dialect and idiolect.

- Geographic dialect corresponds to linguistic variations related to geographic variety. These dialects often entail cultural, social and ideological connotations.

- Temporal dialect is related to the changes which take place throughout time. In this dialect (and in most of them) phonetics is a very important characteristic that should be taken into account (Rica Peromingo and Braga Riera, 2015, p. 125).

- Social dialect or sociolect includes the language variations according to the social class to which the speaker belongs (Hurtado Albir, 2001, pp. 578-579).

- Standard dialect is usually the variety considered as correct, predominating in teaching and media (Rica Peromingo and Braga Riera, 2015, p. 132). Landers (2001, p. 116) points out that it «is merely the dialect spoken by a privileged segment of society that includes its political leaders, its opinion-makers, and its literati».

- Idiolect has to do with the particular characteristics of the speaker, such as recurring structures, distinguished pronunciation or a determined syntax (Hatim and Mason, 1995, p. 61). Rica Peromingo and Braga Riera (2015, p. 132) define idiolect as «uso particular y personal que un hablante 
hace de su lengua: la voz, los sonidos identificables en el habla de esa persona, las construcciones sintácticas utilizadas con mayor o menor frecuencia, la recurrencia de determinadas palabras o expresiones, etc.».

All these linguistic variations, as has been said above, are key in identity configuration, as they serve to "contribute to the depiction of characters»(Alsina, 2020, p.147). Regarding idiolect, this linguistic variation will be the most relevant in the present study, as it is related to the characterisation of a text or a character. As Alsina (2020, p. 147) points out, idiolect is «the individual way each person (or character, in the case of fiction) uses language». Therefore, in this study the term idiolect will be used in order to refer to the user's linguistic characteristics that shape their identity. According to Costa (2006, p. 84) «el idiolecto [...] es lo que singulariza un texto y ese idiolecto está formado, en distintas proporciones, de la lengua general [...], su manifestación espacial, el dialecto, su cara social, el sociolecto».

It can be said, then, that idiolect is essential for the literary character's identitary configuration. It is likewise important in translation, as it allows identify a character through their lexis, linking words or specific syntax (Rica Peromingo and Braga Riera, 2015, p. 133). Idiolect highlights the characters' identity, as it shows «their own distinct and individual version of the language they speak and write, [...] and the assumption that his idiolect will manifest itself through distinctive and idiosyncratic choices in texts» (Coulthard, 2004, p. 431). As has been said, linguistic variation in literature is a fundamental component in identity construction. In this construction, idiolect plays a crucial role as it is an important aspect of the user that clearly shows the overlapping of all varieties (Hatim and Mason, 1995, p. 61). These characteristics will be key to understand Tess Durbeyfield, whose identity revolves around her changing linguistic variation.

\section{THE TRANSLATION OF LINGUISTIC VARIATION}

The translation of linguistic variation is one of the biggest problems in translation studies. The presence of different dialects in a novel is never fortuitous, but with a clear objective. When an author gives their character a dialect, they are differentiating this character from the rest (Tello Fons, 2011, pp. 141-145). Therefore, if the presence of a dialect is always intentional, the translator should take into account the linguistic nuances of the text and highlight the idiolectal and dialectal elements of the character, so the target reader can identify it (Hurtado Albir, 2001, p. 593). Regarding this issue, several interesting theories have been proposed. However, even though there is a wide variety of strategies for the translation of linguistic variation, it 
is merely present in translated literature (Albaladejo, 2012, p. 7). Azevedo defends that

a translation can only be considered successful to the extent that it manages to capture the nuances inherent in the linguistic diversity of the original, in order to preserve, even if in a modified fashion, the manifestation of individual voices, each endowed with a significance of its own (Azevedo, 1998, p. 42).

There is no panacea for dialectal translation. In fact, as Leppihalme (2000, p. 267) points out, the translation of linguistic variation entails the risk of reducing the number of readers, as the great majority does not value the linguistic individuality.

Some of the experts which have worked on this field of dialectal translation are Azevedo (1998), Rabadán (1991), Tello Fons (2011), Catford (1965), Hatim and Mason (1995 and 2005), Mayoral Asensio (1990), Berezowski (1997), Hurtado Albir (2001), Rica Peromingo and Braga Riera (2015), Albaladejo (2012), among others. Regarding the translational strategies that can be used when translating linguistic variation these are innumerable. Azevedo (1998, p. 42) proposes a literary dialect that emulates the linguistic variation of the text. It is a strategy with great potential to generate a lack of familiarity, a lack of standardisation, which encourages the reader to see the character and their speech. In addition, Mayoral Asensio $(1990$, p. 67) defends that there are three approaches for translating dialects: a) to use a dialect in the target language which corresponds with the dialect in the source language; b) to use lexical, grammatical, and syntactic elements in order to express the aforementioned dialect; or c) not to translate the dialect. Sánchez $(2009$, p. 202) opts for similar strategies and affirms that these are: a) to use a dialect from the target language, $b$ ) to use the standard language, $c$ ) to add the description «he/she said with $X$ accent» or d) not to translate the original dialect. On the other hand, Albaladejo (2012, p. 20) defends that there are two major strategies: neutralisation (omitting the original dialect) or recreation (recreating the marked text).

Berezowski (1997, pp. 51-81) proposes the following classification of strategies regarding the translation of dialects:

- Neutralisation: The substandard language is translated with standard language in the target text.

- Lexicalisation: Dialects in the source text are translated only with lexical elements.

- Partial translation: With this strategy, some of the words of the source text are not translated in the target text. 
- Transliteration: This strategy focuses on replacing graphological forms in the source language with phonologic ones in the target language.

- Speech defect: Strategy which highlights «the defects in speakers' phonology as a vehicle of transferring the social deixis of the original» (Berezowski, 1997, p. 62).

- Relativisation: The dialect of the source text is translated with forms of address in the target text.

- Pidginisation: It mainly focuses on the morphological and syntactical characteristics of dialects.

- Artificial variety: Strategy through which an artificial nonstandard language is created.

- Colloquialisation: The linguistic variation of the source text is translated with colloquial elements.

- Rusticalisation: Dialects are translated with marks and terms from the rural world.

Tello Fons (2011) proposes a wide selection of translational strategies for linguistic variation. These strategies are the following (Tello Fons, 2011, pp. 104-131):

Compensation: Some linguistic variations are translated into standard language and some non-dialectal language are marked in the target text. Hatim and Mason (2005, p. 96) define compensation as a «procedure for dealing with any source text meaning [...] which cannot be reproduce directly in the target language".

- Neutralisation: The translation of linguistic variation into standard language.

- Colloquial translation: This strategy entails the use of colloquial language, through phonetic, grammatical or syntactic elements.

- Violation of linguistic norm: Strategy with which ungrammatical language is used in order to mark the character's language and differentiate it from the rest.

- Dialectal translation: The use of a dialect from the target culture with equivalent social, ideological and political characteristics.

As can be observed, there is no unanimity regarding the strategies that should be utilised when translating linguistic variation. There is, however, a recurring pattern among many experts. This pattern can be 
summarised into neutralisation, compensation, colloquial translation and partial translation.

On the other hand, some authors have proposed strategies for the different linguistic variations regarding the user:

- Regarding geographical dialects one can find many discrepancies, from dialectal translation to neutralisation.

- Temporal dialect seems to be very difficult to translate. Rica Peromingo and Braga Riera (2015, p. 216) propose three strategies: a) to translate the archaic effect, b) to use the contemporary language, or $\mathrm{c}$ ) to use contemporary language, but with some archaic flavouring.

- Sociolect can be translated when contexts and social structures are similar in both systems (Rabadán, 1991, p. 115).

- Standard language: There seems to be unanimity among experts, who defend that it should be translated with the standard language of the target culture.

- Idiolect: Catford (1965, p. 86) claims that idiolect does not have to be always translated, as the personal identity is not always an important characteristic. This represents a dangerous affirmation, as identity should always be taken into account, or otherwise the character creation will be modified. Hatim and Mason (1995) defend that idiolect must (and can) be translated.

All these recommendations are merely general contributions. Each translator will take individual decisions, which may not be shared with other experts (Albaladejo, 2012, p. 10). As has been observed, the translation of linguistic variation entails several problems. Dialect and idiolect are challenging for translators, since it is rooted in time, space and in the source culture. In fact, this difficulty is increased in cases where the language variation has not an immediate equivalent in the target language (Azevedo, 1998 , p. 32). Even though there are strategies to translate linguistic variation, Albaladejo $(2012$, p. 20$)$ affirms that the most extended practice in translation is neutralisation, technique through which any substandard aspect in the source text is omitted in the target text, where it is substituted by standard language. Berezowski $(1997$, p. 89) defines neutralisation as the most radical posture in the translation of linguistic variation, as the connotations of the non-standard language are lost, failing to identify the characters in specific social groups (Berezowski, 1997, p. 51). Tello Fons (2011, p. 106) has a similar opinion and defends that if dialectal marks are 
not translated, some connotations and elements of the source text may be irrecoverable. As Azevedo (1998, p. 42) points out, if an idiolect is omitted, the character's configuration will be reshaped. Albaladejo (2012, p. 20) highlights the danger of neutralisation by affirming that this strategy inflicts irrecoverable losses to the marked text. Hurtado Albir (2001, p. 593) claims that if the presence of linguistic variation is never unintentional, the translator has to be able to identify the dialectal and idiolectal marks and translate them to the target text.

\section{TESS OF THE D'URBERVILLES' LITERARY CONTEXT}

Tess of the d'Urbervilles, published in 1891, is considered one of the most famous (and late) novels by Thomas Hardy. This novel is the work that Hardy himself defined as "the beginning of the end of his career as a novelist» (Meek, 2017, p. 51). And he was not mistaken. Hardy's last novel, Jude the Obscure, was published in 1895, four years after Tess's publication

\subsection{Thomas Hardy}

Thomas Hardy (1840-1924) is perhaps one of the most interesting writers from the second half of the nineteenth century England. This may be due to his peculiar style, his ever-changing life or the mixed reception that his controversial topics provoked among the public.

Regarding his style, there seems to be no unanimity. Perhaps the reason as to why it is so difficult to classify Hardy into a literary movement is related to the fact that Hardy's narrative seems to belong to a transition period between Victorian and modern era. Regarding Hardy's style, Taylor (2015, pp. 238-239) claims that it shares the skepticism of the modern time, but at the same time it maintains Victorian aspects. When talking about the novelist's aesthetic, Alvarez affirms that

$$
\begin{aligned}
& \text { his extraordinary originality and that peculiar sense of his being- } \\
& \text { despite the seemingly quaint rural customs which so concerned } \\
& \text { him-a precursor of modernism. The blankness and emotional } \\
& \text { dislocation he delineated so sharply in Tess in } 1891 \text { were to } \\
& \text { become the characteristic note and preoccupation of twentieth- } \\
& \text { century literature (Alvarez, 2012, p. 438). }
\end{aligned}
$$

Hardy was a writer who did not fit into any literary movement, a writer who used his versatility to his advantage. He has one foot in the past and other in the future and he serves as a link to Victorian era, while also moving away from it by initiating tendencies of modern literature (Tello Fons, 2011, p. 210). 


\title{
3.2. Wessex, more than a simple setting
}

Many are the elements that influenced Hardy's professional trajectory, from his childhood in a rural world, to his career as an architect and his classical knowledge. Nevertheless, there is one element that can be considered as the most identifying characteristics of Thomas Hardy's novels: the region of Wessex.

Until 1870, the term Wessex referred to the medieval region located in the Southeast of Great Britain. However, ever since Hardy uncovered this word, Wessex has become a literary where the novelist's characters live. In fact, so identifiable was this region that Hardy was known as the author of Wessex novels. Wessex is a semi-fictional region that serves as location for the great majority of Hardy's novels. Although it does not exist in real life, it is based on a specific geographical location: Dorset, the county in which Thomas Hardy was raised. Regarding this aspect, in the prefaces of Tess of the d'Urbervilles and Far from the Madding Crowd, Hardy wrote:

\begin{abstract}
In the present edition it may be well to state, in response to inquiries from readers interested in landscape, pre-historic antiquities, and especially old English architecture, that the description of these backgrounds in this and its companion novels has been done from the real. (cited in Gatrell, 1999, p. 30).
\end{abstract}

Nevertheless, Hardy did not only inferred a culture and location to his novels, but also particular customs and language. Regarding the latter, of great importance for the current study, the language of Wessex gathers the dialect of Dorset and is rooted in the Anglo-Saxon language (Sorum, 2011, p. 196). Chapman (1990, p. 45) affirms that the dialect of Wessex also includes Latin, Greek and Romance terms. Hardy uses this fictional dialect to differentiate the characters of his novels, to generate a bigger effect if someone with standard pronunciation appears (Butler, 1999, p. 173). As will be seen below, Tess Durbeyfield is characterised by a linguistic duality, as she speaks both the language of Wessex and Standard English. This will be an identifying feature for Tess, highlighting her in the novel, since no other character possesses this duality.

A fundamental aspect for this analysis is the novel's dialogues, as they will help analyse Tess Durbeyfield's idiolect. According to Chapman (1990, pp. 125-128), through the dialogues of Tess of the d'Urbervilles, the reader is immersed in the novel's reality, where they meet the characters and their circumstances. Through their interlocutions the reader is able to grasp the character's identity, their social situation and the changes they suffer in their lives. 
With Wessex, Hardy created a whole culture, where he registered customs and a specific language. For all this reasons, it cannot be said that Wessex is simply a region where Hardy set his work. By imagining this region, Hardy created an undying world, with its own characteristics which make both the setting and its characters unique. Wessex is an essential aspect in Hardy's narrative for the current research, as it entails a world full of habits, with a unique language, pronunciation and syntax which will shape the character's identities in Tess of the d'Urbervilles.

\subsection{Tess of the d'Urbervilles}

As happened with Hardy, Tess of the d'Urbervilles cannot be included in a specific literary movement. Even though it is a late Victorian novel, its descriptive elements and radical ideas anticipate modernism. According to McEarthron (2005, p. 2), Tess's story combines the structure of classical tragedy with a fierce critic towards society and its double morality. Tomalin (2007, p. 230) believes that Hardy was a more modernist than realist writer who, through Tess Durbeyfield, subverts the social prejudice and stereotype of the fallen women. These fallen women represented the immoral side of society, they imposed a threat to England due to their lack of chastity and purity. However, as will be shown below, Thomas Hardy, in the novel's subtitle, uses the term pure to describe Tess Durbeyfield, a character that he knew was going to be considered a fallen woman by his readers. This open attack to Victorian morality was, as one can imagine, not very well received, and thus, was omitted in the first editions of the novel

Hardy, aware of the reactions that his subtitle could arise, still claimed that «you will be surprised to hear that they alter my preface and omit the second title, which is absolutely necessary to show its meaning" (cited in Reilly, 2018, p. 33). For Hardy, the perpetuation of the subtitle was essential for the understanding of the novel and the heroine's identity.

Not only the publishers, but also the readers found the subtitle offensive. Victorian society did not understand how Tess was pure, when her sexual and criminal acts were evident. They did not understand how a fallen woman, a societal stereotype that was condemned in Victorian time, was considered a pure woman. As a response to this critics, Hardy wrote an explanatory note before the publication of the novel:

I will just add that the story is set out in all sincerity of purpose, as an attempt to give artistic form to a true sequence of things; and in respect of the book's opinions and sentiments, I would ask any too genteel reader, who cannot endure to have said what everybody nowadays thinks and feels, to remember a well-worn sentence of 
St. Jerome's: If an offence come out of the truth, better is it that the offence come that that the truth concealed (Hardy, 1991, p. IX).

However, negative the reception of Tess was, it is nowadays considered one of the greatest works by Thomas Hardy. Its popularity comes from the empathetic, subtle and deep uncover of Tess's suffering, a pure woman who is ill-treated by society. Perhaps the reasons of the misunderstanding of both Hardy and Tess has to do with the fact that neither of them belong to the time in which they were born. Bloom (2010, p. 12) follows this theory and affirms that «Hardy's novel [Tess] has proved to be prophetic of a sensibility by no means fully emergent in $1891 »$.

\section{Methodology}

Tess of the d'Urbervilles is a novel in which, as said before, dialogues are crucial. That is why for the present study, dialogues and interventions have been the main focus for analysing the linguistic variation in Tess Durbeyfield. The dialogues' analysis has been made in a two-stage process. The first phase focused on analysing the original novel, whereas the second stage was related to the dialogue's selection of the three translations.

The original novel, with an extension of 314 pages $^{1}$, has 2298 quotes. The subtraction of all the novel's original dialogues has been carried out with two different processes. First, the web application of CLiC has been used in order to differentiate all the quotes of the novel from the rest of the narration. Afterwards, a manual selection has been needed in order to classify the dialogues (usually composed by several quotes) into the different characters (Tess, Alec, Angel, Tess's family, Tess's friends and society). Once all interventions have been grouped into characters or characters' groups, only those in which Tess Durbeyfield is a participant have been selected. In total, the heroine appears in 86 dialogues.

After having finished the first stage of the dialogues' subtraction, it was necessary to analyse all three translated versions. In this last phase, the methodology used has been mainly a manual selection of the already classified dialogues, both in the digital and physical formats. Due to the extension of the current study, a second round of dialogue selection was needed, in which only the most relevant ones have been included. These selected dialogues show the linguistic variation and the duality in Tess Durbeyfield's idiolect, as will be seen below.

${ }^{1}$ Data from Critical Norton edition.

Hikma 20 (2) (2021), 177 - 202 


\section{ANALYSIS: TESS DURBEYFIELD'S LINGUISTIC VARIATION AND ITS TRANSLATION INTO SPANISH}

For this analysis, the original text and the three Spanish translations of Tess of the d'Urbervilles will be analysed. The original text that will be utilised was published by Norton Critical Edition in 1991. Regarding the translated versions, the first translation, which dates back to 1924, was carried out by Manuel Ortega y Gasset. For this research a later reprint will be used, published in 1942 by the publisher Nausica. The second translation of Tess was translated by Javier Franco Aixelá in 1994 and published by Temas de Hoy. Finally, the last translation of the novel was published in 2017 by Alba editorial and translated by Catalina Martínez Muñoz.

\section{TESS OF THE D'URBERVILLES' SUBTITLE}

Tess Durbeyfield is the pillar of the novel, whose identity can be traced from her linguistic variation and the changes it suffers throughout the story. Due to the fact that Tess Durbeyfield is the heart of the story, the subtitle that Hardy gave the Victorian novel is essential to understand the main heroine's characterisation. The title of the novel is accompanied by the subtitle «A pure woman faithfully presented by Thomas Hardy». With the adjective pure Hardy identifies Tess as a woman free of guilt, who despite all events that take place in her life, remains pure. The subtitle does not blame the raped, the murder, but the rapist, the aggressor and those who participated in Tess's tragedy.

\begin{tabular}{|c|c|c|c|}
\hline HARDY, 1991 & $\begin{array}{c}\text { ORTEGA Y } \\
\text { GASSET, 1942 }\end{array}$ & $\begin{array}{c}\text { FRANCO AIXELÁ, } \\
\mathbf{1 9 9 4}\end{array}$ & $\begin{array}{c}\text { MARTíNEZ } \\
\text { MUÑOZ, 2017 }\end{array}$ \\
\hline $\begin{array}{c}\text { A pure woman } \\
\text { faithfully } \\
\text { presented by } \\
\text { Thomas Hardy }\end{array}$ & $\varnothing$ & $\varnothing$ & $\begin{array}{c}\text { Una mujer pura } \\
\text { fielmente } \\
\text { presentada por } \\
\text { Thomas Hardy }\end{array}$ \\
\hline
\end{tabular}

Figure 1. The translation of the subtitle

Source: The authors

Nevertheless, as can be observed in fig. 1, in the translations from 1942 and 1994 the subtitle does not appear, nor there is a reference of this key quality of Tess. With this suppression, Tess's story is altered, a pure woman who lives in a pure Wessex and where they both are corrupted and mistreated by the world (Alvarez, 2012, p. 478). 


\section{FROM TESS DURBEYFIELD TO TESS D'URBERVILLE}

Tess Durbeyfield is with no doubt the most complex character in the novel. One of the most important aspects in Tess's configuration, pertinent for this research, is her duality, both appellative and linguistic. According to Ragussis (1986, pp. 141-142) the dual names of the novel (Blackmore/Blackmoor or Durbeyfield/d'Urberville) indicate the double nature of Tess, who is at the same time an aristocrat and a dairywoman. On the other hand, Tess has a linguistic duality, as, depending on the context, she uses the Wessex rural dialect or Standard English ${ }^{2}$. Tess's duality become evident when compared with her mother's (dialogue 1) and brother's (dialogue. 2) linguistic variations. This duality can also be observed from dialogues 1 to 10 .

In relation to Tess's evolution throughout the novel, Shires (1999, p. 154-155) affirms that she suffers a very significant change, since «the novel takes her from being a she, to a collection of aspects, to an it, and ultimately to a nothingness». This evolution will affect Tess's idiolect, which will be shaped according to the circumstances and experiences of the heroine. As the novel progresses and Tess's terrible end is predicted, her idiolect will be transformed, altered by the events and characters that shape Tess's life (as can be observed in dialogues 11, 12 and 13).

\subsection{Linguistic difference between Tess and her mother}

$1(\mathrm{a})$

"Had it anything to do with father's making such a mommet of himself in thik carriage this afternoon?-Why did 'er?" (Hardy, p. 12)

1 (b)

- ¿Tiene algo que ver con eso que ha hecho padre de pasearse esta tarde en coche? (Ortega y Gasset, p. 24)

$1(\mathrm{c})$

- ¿Tiene algo que ver con padre haciendo el payaso en aquel carruaje esta tarde? ¿Cómo se le ha podido ocurrir? (Franco Aixelá, p. 38)

$1(d)$

\footnotetext{
2It should be noted that Tess's linguistic duality suffered several changes in the novel. At first, in the 1891 edition, it is said that Tess only uses the dialect "when excited by joy, surprise, or grief (Hardy, [1891] 2012, p. 20). However, this description was eliminated and replaced by «Tess] spoke two languages; the dialect at home, more or less; ordinary English abroad and to persons of quality» (Hardy, [1891] 1991, p. 12).
} 
- ¿Tiene algo que ver con la que ha armado padre esta tarde en el coche? ¿Por qué ha hecho eso? (Martínez Muñoz, p. 37)

In this dialogue, present at the beginning of the novel, Tess's dialect can be very clearly observed. In relation to the phonetic aspects, the dialectal determiner thik (that) and the pronoun 'er (he) can be found. The three translations neutralise the substandard language, omitting Tess's Wessex dialect. The main character is able to use both standard and dialectal language, something that makes her stand out in the novel. If in translation this feature is omitted, Tess's identity will be reshaped in the target texts.

On the other hand, in relation to the lexical aspects, the term mommet (effigy, puppet, scarecrow) should be highlighted. Martínez Muñoz uses a colloquialism in order to compensate the dialectal mark and the relaxed speech of Tess when she is surrounded by family members. On the contrary, Ortega y Gasset neutralises the dialectal structure by using the structure eso que ha hecho. On the other hand, Franco Aixelá uses a term that, although it is considered standard (payaso), has a powerful semantic meaning, showing the proud nature of Tess.

\subsection{Linguistic difference between Tess and her brother}

2 (a)

"That our great relation will help 'ee to marry a gentleman."

"I? Our great relation? (Hardy, p. 20)

2 (b)

-Claro, mujer. Porque nuestros parientes ricos te buscarán un novio rico como ellos.

- ¿Nuestros parientes ricos? (Ortega y Gasset, pp. 36-37)

2 (c) caballero.

- Sí, de que nuestra parienta importante te ayude a casarte con un

— ¿Yo? ¿Nuestra pariente importante? (Franco Aixelá, p. 50)

2 (d)

-Que esa pariente noble te ayude a casarte con un caballero.

— ¿Yo? ¿Esa pariente noble? (Martínez Muñoz, p. 49) 
This dialogue, held between Tess and her brother Abraham, shows once again Tess's linguistic duality. Before analysing the identitary aspects, it should be noted that Tess professes a maternal feeling towards their siblings, reflected in the way she expresses herself, using a less marked dialect, since she tries to speak in a more corrected way ${ }^{3}$.

In the original text, the phonetic element 'ee (you) can be highlighted. As in the previous example, the general strategy is neutralisation, with which the dialectal mark is omitted. However, regarding the lexical aspects, the strategy of compensation can be observed in Franco Aixelá's translation. The translator does not use any dialectal mark for the translation of 'ee; he opts, however, for a substandard structure for the translation of great relation. In order to reflect the idiolectal differences between siblings, Franco Aixelá uses the strategy of violation of linguistic norm. This way, the translator uses the dichotomy parienta/pariente to express Tess's standard language opposite to Abraham's substandard speech.

If Abraham's dialect is neutralised, there is no difference between Tess's and her brother's idiolect. In the 1942 and 2017 translations, both characters make use of the standard language, making it difficult to appreciate that Tess has a higher education than Abraham.

\subsection{Linguistic difference between Tess and Alec d'Urberville}

3 (a)

"Our names are worn away to Durbeyfiled: but we have several proofs that we are d'Urbervilles. Antiquarians hold we are [...] (Hardy, pp. 28-29)

3 (b)

-Nuestro apellido se ha ido desfigurando hasta parar en Durbeyfield, pero podemos probar que nos llamamos de Urbervilles. Los anticuarios sostienen que lo somos... [...] (Ortega y Gasset, pp. 50-51)

3 (c)

-Nuestro apellido ha degenerado a Durbeyfield, pero tenemos varias pruebas de ser d'Urberville. Los anticuarios lo afirman. [...] (Franco Aixelá, p. 62)

\footnotetext{
${ }^{3}$ «As Tess grew older, and began to see how matters stood, she felt quite a Malthusian towards her mother for thoughtlessly giving her so many little sisters and brothers, when it was such a trouble to nurse and provide for them. [...] However, Tess became humanely beneficent towards the small ones, and to help them as much as possible she used, as soon as she left school». (Hardy, 1991, pp. 24-25)
} 
3 (d)

-Nuestro apellido se ha ido viciando hasta acabar en Durbeyfield, pero tenemos pruebas de que somos d'Urberville. Los que estudian las cosas antiguas nos han asegurado [...] (Martínez Muñoz, pp. 60-61)

Here can be seen how Tess's idiolect suffers a transformation when addressing to a noble person. As has been said, Tess's linguistic duality allows her to shift from Wessex dialect to standard language. This distinction is clear in the translations of Ortega y Gasset and Franco Aixelá, where the higher syntax and language have been maintained. In these versions terms such as desfigurar, degenerar or anticuarios can be found, with which the idiolectal change in Tess becomes visible.

However, in Martínez Muñoz's version a new strategy can be found, one that could be named as «linguistic decrease». With it, the translator decreases Tess's idiolect by translating antiquatians into «los que estudian las cosas antiguas». In the original, Tess uses a specific term, translated by neutral elements in the target text. By doing so, perhaps the linguistic difference between Alec, born noble, and Tess, with rural background, is highlighted. Nevertheless, if Tess's high language is not maintained, in the latest translation one cannot see how the heroine shifts her idiolect depending on to whom she talks.

7.4. Difference between standard and substandard language in Tess Durbeyfield

4 (a)

"What a mommet of a maid!"

"But I don't care! O no-I don't care! I'll always be ugly now." (Hardy, pp. 219-220)

4 (b)

— ¡Vaya una momia de muchacha! p. 104)

-Pero ¡qué importa! Yo ahora quiero parecer fea. (Ortega y Gasset,

4 (c)

—iQué fea es!

- ¡Pero no me importa! ¡No, no me importa! A partir de ahora siempre seré fea. (Franco Aixelá, p. 357)

$4(d)$ 
—QQué adefesio!

—Pero me da igual. ¡Sí, me da igual! A partir de ahora siempre seré fea. (Martínez Muñoz, pp. 341-342)

In this example, Tess's duality can be very well appreciated, with the parallelism between the dialectal term mommet, used by a farmer, and the standard term ugly, spoken by Tess. Both terms carry a very similar meaning. Through these elements, Tess's distinctive idiolect can be observed, who uses the standard language in comparison with the farmer's Wessex dialect.

For the translation of these terms, Franco Aixela uses the strategy of neutralisation, omitting the aforementioned parallelism since he uses in both cases the adjective fea. The other translations have used various terms, differentiating the idiolect of each character. Ortega y Gasset has opted to use momia and fea. Regarding the former, it should be noted that, although it does not correspond with any meaning for the word mommet, it may maintain the dialectal effect by employing a colloquialism. This same strategy can be found in Martínez Muñoz's version, where the colloquial word adefesio can be found. This way, both translators differentiate Tess's idiolect and the dialectal speech of the farmer. In the intervention, there are also phonetic aspects, represented by the pronoun 'em. As can be seen, none of the translations maintain the substandard element.

The lexical parallelism reflects Tess's idiolect. She, although her native language is the dialect of Wessex, chooses to use a non-dialectal term. If the distinction is not maintained, Tess's and the farmer's idiolects are the same, decreasing the complexity of Tess's character.

\subsection{Other examples of Tess Durbeyfield's linguistic duality}

Throughout the novel, Tess constantly changes from dialect to standard language. As has been said, this is one of the key features of the heroine, whose duality is not only linguistic, but also identitary. In the following dialogues $(\mathrm{a}-\mathrm{c})$ this distinction between Wessex and standard language can be observed. Nevertheless, all translations use the strategy of neutralisation, omitting the substandard elements in Tess's speech.

A) 'Twould be / It would be

5 (a)

"I shouldn't care to do that. If there is such a lady 'twould be enough for us if she were friendly —not to expect her to give us help." (Hardy, p. 24)

6 (a) 
"But I did not think it would be like this. I came, sir, to tell you that we are of the same family as you." (Hardy, pp. 28-29)

5 (b)

-De muy buena gana lo haré. Si existe tal señora, no nos vendría mal que nos dispensase buena acogida, y nada de particular tendría que nos prestase ayuda (Ortega y Gasset, pp. 44-45)

6 (b)

-Sólo que no creí que la cosa fuera como es. Venía, sir, a participarles a ustedes que somos de la misma familia. (Ortega y Gasset, pp. 50-51)

5 (c)

-No me parece una buena idea. Si existe esa señora, ya nos sobraría con que fuese amable, y no deberíamos esperar que nos ayudase (Franco Aixelá, pp. 55-56)

6 (c)

-Pero no creí que fuera a ser así. Vine, señor, a decirles que somos de la misma familia que ustedes. (Franco Aixelá, p. 62)

5 (d)

-No quiero. Si existiera esa señora, ya sería demasiado que nos tratara con amabilidad, pero no podemos esperar ayuda (Martínez Muñoz, pp. 55-56)

$6(d)$

—Pero no me lo imaginaba así. He venido, señor, para decirles que somos de la misma familia. (Martínez Muñoz, pp. 60-61)

Tess's linguistic duality can be seen through the distinction between the structures 'twould be and it would be. As can be observed, this dichotomy is neutralised in the three translations, where the substandard marks are substituted by standard language. With this strategy, the idiolectal difference of Tess is deleted, transfiguring her identity.

B) 'Twas / It was

7 (a) 230-231)

"Pooh — the he didn't mean it. 'Twas just a man's jest!" (Hardy, pp. 
8 (a)

"I didn't understand your meaning till it was too late."

“That's what every woman says." (Hardy, p. 60)

7 (b)

— ¡Bah!... No tendría mucho interés entonces... ¡Sería un capricho de esos que les dan a los hombres!... (Ortega y Gasset, pp. 122-123)

8 (b)

-No comprendí lo que usted se proponía hasta que ya era tarde.

—Eso es lo que dicen todas. (Ortega y Gasset, p. 108)

7 (c)

— ¡Bah... entonces es que no lo decía en serio! ¡No fue más que una de esas chanas que hacen los hombres! (Franco Aixelá, p. 373)

8 (c)

-No comprendí lo que pretendías hasta que fue demasiado tarde.

—Eso es lo que dicen todas las mujeres. (Franco Aixelá, pp. 111-112)

7 (d)

— ¡Bah! ¡No lo diría en serio! ¡Sería una broma de esas que gastan los hombres! (Martínez Muñoz, p. 356)

8 (d)

-No entendí lo que buscabas hasta que ya era demasiado tarde.

-Eso dicen todas las mujeres. (Martínez Muñoz, p. 109)

In this example, Tess makes an alternation between it was (standard language) and 'twas (dialectal language). Nevertheless, her linguistic variation is mitigated in all translations, as there are no dialectal marks in Tess. All translators have decided to use the standard language in both fragments, omitting Tess's linguistic duality. This alteration is clearer in Franco Aixelá's version, who uses fue for the translation of both the standard and dialectal language.

C) ‘Ee / You

9 (a)

"And if you go away from me I shall not follow 'ee (Hardy, p. 180) 
$10(a)$

"O my love, my love, why do I love you so! (Hardy; p. 168)

9 (b)

35)

—Y si te vas de mi lado, no te he de seguir. (Ortega y Gasset, pp. 34-

10 (b)

- ¡Ay, amor mío, por qué te quiero tanto! (Ortega y Gasset, pp. 1415)

9 (c)

—Y si me abandonas no te seguiré (Franco Aixelá, p. 298)

10 (c)

—Mi amor, mi amor, por qué te amaré tanto! (Franco Aixelá, p. 279)

9 (d)

—Y, si me dejas, no te seguiré. (Martínez Muñoz, pp. 283-284)

10 (d)

-iAy, mi amor! ¿Por qué te querré tanto? (Martínez Muñoz, p. 266)

In these dialogues, Tess Durbeyfield's linguistic duality is again evident, due to the apparition of the personal pronouns you, which corresponds to the standard language, and ye, with a dialectal mark. However, the Spanish translations omit the substandard language, and with it, Tess's linguistic variation.

\subsection{Identity change in Tess Durbeyfield}

11 (a)

"The trees have inquisitive eyes, haven't they? -that is, seem as if they had. And the river says 'Why do ye trouble me with your looks?' (Hardy, p. 97)

11 (b)

—Los árboles tienen ojos de curiosidad, ¿no es cierto?... Es decir, que parece como si los tuvieran. Y el río va diciendo: "¿Por qué me miráis?" (Ortega y Gasset, p. 175)

11 (c) 
- Los árboles tienen ojos inquisitivos, ¿no le parece? Quiero decir que parece como si los tuvieran. Y el río dice: «¿Por qué me molestas con tu aspecto?» (Franco Aixelá, pp. 170-171)

$11(d)$

-Los árboles tienen unos ojos interrogantes, ¿verdad? $\mathrm{O}$ sea, parece que los tengan. El río dice: «¿Por qué me molestas con tus miradas?». (Martínez Muñoz, p. 162)

As happened in previous examples, Tess's dialect is highlighted by the pronoun ye. The strategy of all translations is neutralisation. In addition, through her words a change in her personality can be observed: the happy, energetic Tess present in the beginning of the novel leads now to a melancholic and sad Tess. This transformation can be seen in the sentence the trees have inquisitive eyes, with which Tess refers to the inquisitive eyes of society, who condemns her. As can be inferred, the lexical term inquisitive has a strong meaning in Tess's idiolect. It should be noted that she constantly feels the social pressure for having been raped. She does not consider herself pure, nor worthy of marriage. Thus, if terms with different connotations are used (as in Ortega y Gasset's and Martínez Muñoz's versions), the constant guilt, very characteristic in Tess, may be altered.

\subsection{Passiveness in Tess Durbeyfield's idiolect}

12 (a)

"Nobody loves it; nobody sees it." (Hardy, p. 237)

12 (b)

—Nadie me quiere ni me mira (Ortega y Gasset, p. 133)

12 (c)

—Nadie lo ama, nadie lo ve. (Franco Aixelá, p. 383)

$12(d)$

—Nadie me quiere ni me mira. (Martínez Muñoz, p. 364)

In this part of the novel, Angel discovers Tess's past and decides to abandon her. This dialogue reflects a great change in Tess's personality, as she does not care about her aspect or her condition and refers to herself with the neutral pronoun it. The translation which best maintains this effect is Franco Aixelá's, who uses the pronoun lo. However, this may create ambiguity as the pronoun can be understood as a way to referring Angel, and not Tess. On the other hand, Ortega y Gasset and Martínez Muñoz omit 
the idiolectal feature, using the pronoun me. By using this pronoun, the repercussion that the rape entails in Tess's idiolect disappear. By not maintaining the pronoun it, the passiveness in Tess, who does not consider herself human, but an object, a thing, is lost in translation.

\subsection{Tess Durbeyfield's last words}

13 (a)

"It is as it should be! Angel—I am almost glad-yes, glad! This happiness could not have lasted -it was too much - I have had enough; and now I shall not live for you to despise me. I am ready" (Hardy, p. 312)

13 (b)

-No tenía más remedio que ser así. Angel, después de todo, me alegro. Sí..., estoy muy contenta... Esta felicidad no podía durar mucho...; ya ha durado demasiado... He gozado bastante; ya no quiero vivir más, no sea que vayas a despreciarme... ¡ Vamos! (Ortega y Gasset, p. 265)

13 (c)

-Es como debe ser. Angel, estoy casi contenta... ¡Sí, contenta! Esta felicidad no hubiera durado. Era demasiado. Yo ya tengo suficiente y no viviré para ver cómo me desprecias. Estoy dispuesta (Franco Aixelá, p. 500)

13 (d)

-Así tenía que ser. Casi estoy contenta, Angel. Sí, ¡contenta! Esta felicidad no podía durar. Era demasiada. He sido muy feliz, y no quiero seguir viviendo para ver que puedas llegar a despreciarme. Estoy lista. (Martínez Muñoz, pp. 475-476)

This words perfectly correspond to the main character's identity. As has been said earlier, Tess feels guilty for the sin that she has committed, and is aware that her husband will repudiate her for the murder of Alec. Therefore, the words «it is as it should be» express how Tess accepts her punishment. In relation to this sentence, it is necessary to highlight Martínez Muñoz's translation, as the strength and energy of Tess is maintained.

Regarding the lexical aspects, the term glad should be mentioned, translated in all versions into contenta. Ortega y Gasset adds the modifier muy, altering Tess's identity, as she is almost glad, because she does not want to see how Angel will despise her. On the other hand, in relation to the morphosyntactic aspects, the sentence «l am ready» should be analysed. Martínez Muñoz seems to better maintain Tess's idiolect, who has accepted her end. The resignation or fulfilment does not seem to appear in the other 
translations. The translation of Ortega y Gasset has a modulation, in which the compensation strategy can be observed, by adding exclamation marks. However, in the original Tess accepts her future solemnly, thus these marks may alter her identity.

\section{CONCLUSIONS}

The translation of linguistic variation, as has been said, is an aspect with no easy solution nor unanimous, due to the wide variety of translation strategies and the difficulty of transferring dialects in target texts. In linguistic variation, idiolect is one of the pillars for identity configuration, as with a mere sentence or term the reader is able to identify a character.

As has been observed in this project, Tess Durbeyfield is a very complex character, with a very marked idiolect and a wide register. She is able to use both the standard language and Wessex dialect, depending on the context and her interlocutor. This peculiar feature distinguishes her from the rest of the characters in the novel, who use either the standard language (such as Angel Clare or Alec d'Urberville) or the Wessex dialect (such as Tess's family and friends), but they never use both. This aspect is key to understand the complexity of Tess Durbeyfield. In some cases, the linguistic variation found in the original has been translated with different strategies such as colloquialism, compensation, or violation of the linguistic norm. These strategies seem to usually occur in lexical and morphosyntactic structures. Nevertheless, regarding dialectal structures, neutralisation seems to predominate in all translations. This decision alters Tess's identity, no longer characterised by a linguistic duality, as the vast majority of dialectal language is neutralised in all three translations. As a result, Tess is no longer a complex and dual character, capable of modulating her idiolect, and whose language illustrates the tragic events in her life. In the translated texts, Tess's speech is marked with mostly standard language, which makes her idiolect more similar to that of Alec and Angel, and distances her from the Wessex rural world. This neutralisation can lead to the reader's failing to differentiate Tess's idiolect (and identity) from the rest or to perceive the changes the heroine's idiolect suffers throughout the novel.

It can be said, therefore, that a fundamental aspect in order to preserve the character's identity resides in their idiolect. If their linguistic variation is not maintained, the difference between characters will be decreased, or even omitted. With idiolects, one can know the story behind a character, their origin, social class, the time in which they live, their ideology, and education. Regarding Tess Durbeyfield, the reader can see in her interventions that she grew up in a rural background (therefore, she was raised with Wessex dialect) but that she also received an education from 
which she adopted features of the standard language. The combination of her education and her upbringing gives her a very interesting linguistic duality. However, if idiolects are altered, this presupposed story may remain hidden. That is why linguistic variation should be reflected in target texts, as it provides the literary texts and its characters with unique features. As has been said before, the apparition of linguistic variation in a text is always deliberate. Therefore, it should not be omitted in translation, since it could lead to a distortion of not only the characters, but the text itself.

\section{REFERENCES}

Albaladejo Martínez, J. A. (2012). La estética como factor determinante en la traducción del texto literario dialectal y socialmente marcado. Hermēneus, 14, pp. 1-22.

Alsina, V. (2020): The translation of idiolect in children's literature: The Witches and Matilda by Roald Dahl. In Fischer and Naro (Eds.) Translating Fictional Dialogue for Children and Young People (pp. 145-164). Germany: Frank \& Timme.

Alvarez, A. (2012): Tess of the d'Urbervilles. In Thomas Hardy Tess of the d'Urbervilles (. 475-487), St Ives: Penguin Books.

Azevedo, M. M. (1998): Orality in Translation: Literary Dialect from English to Spanish and Catalan. Sintagma, 10, pp. 27-43.

Berezowski, L. (1997): Dialect in Translation, University of Wrocław: Editorial Board.

Bloom, H. (2010): Thomas Hardy. New York: Bloom's Literary Criticism.

Butler, L. (1999): Registering the Difference: Reading Literature through Register, New York: Manchester University Press.

Catford, J. C. (1965): «Language Varieties in Translation», in A Linguistic Theory of Translation, Aylesbbury: Oxford University Press, pp. 83-92

Chapman, R. (1990): The language of Thomas Hardy. London: Macmillan Education.

CLiC Web App, «Tess of the d'Urbervilles», University of Birmingham and University of Nottingham.

Costa, W. C. (2006): Traducción literaria, variedad e idiolecto. Alteria, 22 (1), pp. 83-89.

Coulthard, M. (2004): Author Identification, Idiolect and Linguistic Uniqueness. Applied Linguistics, 25 (4), pp. 431-447. 
Gatrell, S. (1999): Wessex. In Dale Kramer (Ed.) The Cambridge Companion to Thomas Hardy (pp. 19-37). Cambridge: Cambridge University Press.

Hardy, T. ([1891] 1942): Teresa de Urbervilles (translator: Ortega y Gasset, M), vol. 1 and 2, Barcelona: Nausica.

Hardy, T. ([1891] 1991): Tess of the d'Urbervilles. Nueva York: Critical Norton.

Hardy, T. ([1891] 1994): Tess d'Urberville (translator: Franco Aixelá, J.). Madrid: Temas de hoy.

Hardy, T. ([1891] 2012): Tess of the d'Urbervilles. St Ives: Penguin Books.

Hardy, T. ([1891] 2017): Tess de los d'Urberville (translator: Martínez Muñoz, C). Barcelona: Alba Editorial.

Hatim, B. y Mason, I. (2005): The translator as communicator. London: Routledge.

— (1995): Teoría de la traducción. Una aproximación al discurso. Barcelona: Ariel.

Hurtado Albir, A. (2001): Traducción y traductología. Introducción a la traductología. Madrid: Cátedra.

Landers, C. E. (2001): Literary translation. A Practical Guide. Great Britain: Multilingual Matters.

Leppihalme, R. (2000): The two faces of Standardization: On the Translation of Regionalisms in Literary Dialogue. The Translator. Studies in Intercultural Communication. Evaluation and Translation, Special Issue, 6 (2), pp. 271-293.

Mayoral Asensio, R. (1990): "Comentario a la traducción de algunas variedades de lengua», in II Encuentros complutenses, Actas del IULMYT. Web. Centro Virtual Cervantes, pp. 65-71.

Mcearthron, S. (2005): Thomas Hardy's Tess of the d'Urbervilles. A sourcebook, Oxford: Routledge.

Meek, S. (2017): The silent indiscretion: Rethinking censorship in Thomas Hardy's An indiscretion in the life of a heiress. The Thomas Hardy Journal (33) p. 51-60.

Rabadán, R. (1991): «La inequivalencia: ¿imposibilidad o límite?», in Equivalencia y traducción. Problemática de la equivalencia 
translémica inglés-español, Zamora: Universidad de León, pp. 109170.

Ragussis, M. (1986): Acts of naming, Oxford: Oxford Univertiy Press

Reilly, P. (2018): The Dark Landscape of Modern Fiction; Routledge: New York.

Rica Peromingo, J. P. Y Braga Riera, J. (2015): Herramientas y técnicas para la traducción inglés-español: los textos literarios, Salamanca: Escolar y Mayo.

Sánchez, M. (2009): The problems of literary translation: A Study of the Theory and the Practice of Translation from English into Spanish, Berna: International Academic Publishers.

Shires, L. M. (1999): The radical aesthetic of Tess of the d'Urbervilles. In Dale Kramer (Ed.) The Cambridge Companion to Thomas Hardy (pp. 145-163). Cambridge: Cambridge University Press.

Sorum, E. (2011): Hardy's Geography of Narrative Empathy. Studies in the Novel, 43 (2), pp. 179-199.

Taylor, D. (2015): Hardy's Poetry. In Phillip Mallet (Ed.) Thomas Hardy in Context (pp. 231-241), Cambridge: Cambridge University Press.

Tello Fons, I. (2012): Traducción de la variación lingüística: una visión diacrónica. Hikma, 11, pp. 133-159.

- (2011): La traducción del dialecto: análisis descriptivo del dialecto geográfico y social en un corpus de novelas en lengua inglesa y su traducción al español (tesis doctoral), Universidad Jaume I: Castellón

Tomalin, C. (2007): Thomas Hardy. The Time-Torn Man, Suffolk: Penguin Books. 